\title{
Investigation of the effect of the virtual reality application on experimental pain severity in healthy
}

Dilek Karaman ${ }^{1}$

(iD) Funda Ero/2

(D) Dilek Yılmaz ${ }^{3}$

Yurdanur Dikmen ${ }^{2}$

1. Department of Health Care Services, Ahmet Erdogan Health Services Vocational School, Bulent Ecevit University, Zonguldak, Turkey 2. Department of Nursing, Sakarya University Faculty of Health Sciences, Sakarya, Turkey 3. Department of Nursing, Bursa Uludag University Faculty of Health Sciences, Bursa, Turkey

\section{SUMMARY}

OBJECTIVE: This study aimed to investigate the effect of virtual reality application on experimental ischemic pain created with a blood pressure instrument in healthy volunteers.

METHODS: The research sample consisted of 172 volunteer adult students who conformed to the inclusion criteria. These individuals were assigned into an experimental $(n=86)$ and a control group $(n=86)$ by a simple randomization method. All individuals in the experimental and control groups wereexperimentally subjected to pain for two minutes by applying $260 \mathrm{mmHg}$ of pressure 3-4 cm above the antecubital region of the left arm with an aneroid adult-type blood pressure instrument. During the procedure, the volunteers in the experimental group watched virtual reality images, while those in the control group received no intervention. Immediately after the procedure, the pain levels of the individuals in both groups were assessed with a Visual Analog Scale (VAS).

RESULTS: We found that the mean pain score of the individuals in the experimental group was 2.62 \pm 1.82 , and that of individuals in the control group was 5.75 7.65 . Results of the statistical analysis showed a statistically significant difference between the mean pain scores of the individuals in the experimental and control groups $(p<0.001)$.

CONCLUSION: This study found that the use of virtual reality was effective in reducing the level of pain in healthy individuals. This method used a smartphone with widespread availability and ease of transportation, which can be used by health professionals as a non-pharmacological method in the management of pain.

KEYWORDS: Virtual Reality. Pain. Distraction.

\section{INTRODUCTION}

Distraction is a cognitive behavioral technique used to reduce the sensation of pain'. This technique has been developed following theories that attempt to explain the mechanism of pain, which was initially seen as a reflex event. In opposition to this idea, Melzack and Wall ${ }^{2,3}$ proposed that pain signals do not reach the brain as soon as damage is caused. According to the Gate Control Theory that they developed, gate mechanisms exist at the level of the spinal cord and control the passage of pain. According to the neurocognitive model of attention to pain, which supports this theory, when more than 
one sensory signal arrives at the brain at the same time, the strongest is chosen and reaches the level of consciousness ${ }^{4}$. Thus, it is maintained that drawing a person's attention away from pain will reduce the level of pain felt ${ }^{1}$.

The use of virtual reality (VR) based on the gate control theory is a method which uses attention processes to achieve a distancing from pain ${ }^{5}$. It is a simulation model which gives participants a feeling of reality, created by computer, and allows interaction. Today, three dimensional VR is possible on a smartphone by dividing the screen into two (for right and left eye images). A smart device can create a multi-dimensional and realistic image using a headset ${ }^{6-8}$. In this way, VR functions as a non-pharmacological method in the management of pain using cognitive and attention processes on the complex pain modulation system of the body ${ }^{9}$.

Recently, the use of VR in pain management in health care has become more widespread. Studies in the literature show the effectiveness of VR in pain management in operations such as the debridement of burns, episiotomy, wound care, dental treatment, endoscopy, insertion of catheters, and chemotherapy $^{10-15}$. Contrary to the results of these studies, others have reported that VR was not effective in pain management ${ }^{16-17}$. There are differences in the efficacy of its application in studies conducted on patients. Therefore, determining the effectiveness of the appli- cation in healthy individuals can provide a chance to evaluate it by eliminating factors which could affect pain levels such as the hospital environment, the psychology of being sick, the effects of analgesics, and the clinical situation ${ }^{13,16}$. This study aimed to determine the effect of virtual reality on the level of pain inflicted experimentally to healthy individuals by eliminating factors which could affect pain in the clinical environment.

\section{METHOD}

This was a randomized, single-blind, quasi-experimental study.

\section{Setting and sample}

The research was conducted between July and September 2017 at a university in the north of Turkey. The research sample consisted of 172 students, all healthy males and females. After a pilot study, a certain number of samples was collected, and a power analysis was performed using descriptive statistics. The sample size of each experimental group was calculated as 86 for 0.90 power. The relevant calculation was made using PASS 13.0 (PASS, Kaysville, Utah, USA).

The criteria for inclusion in the study were as follows: not having problems such as fracture, dislocation, crushing of the soft tissue or any circulation disorder of the upper limbs, no diseases which could

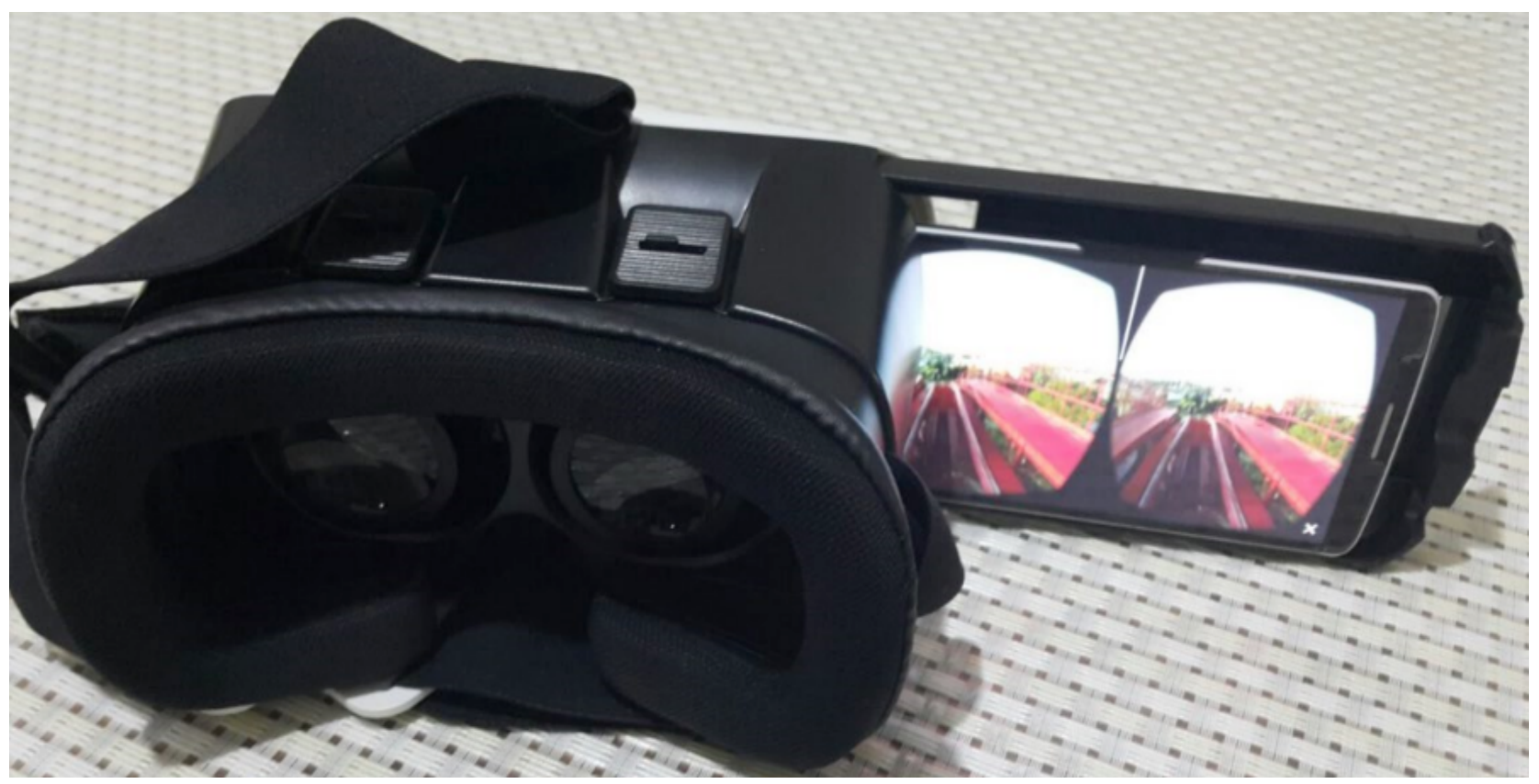

FIGURE 1. THE VR EQUIPMENT USED IN THIS STUDY WITH "ROLLER COASTERS" MEDIA WATCHED USING A SMARTPHONE LOCATED IN A VRBOX HEADSET. 


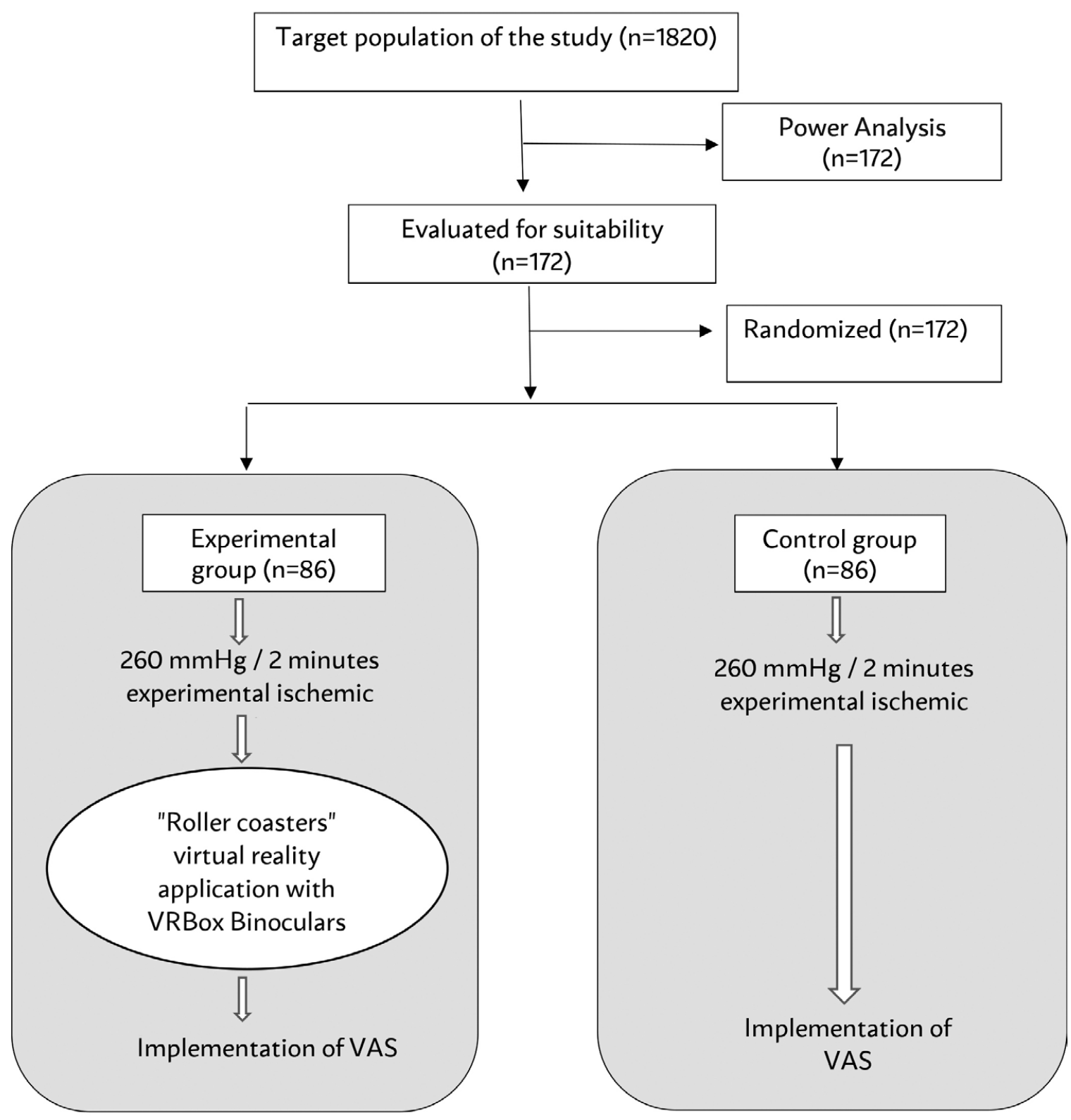

FIGURE 2. THE RESEARCH DESIGN APPLIED IN THIS STUDY

affect pain, no sight or hearing impairments. The students selected were not students of any of the researchers conducting the study and had no relationship of mutual interest with the teachers.

The students were randomized according to age and gender and randomly divided into an experimental and a control group using the coin method. Listed students were allocated into the experimental group ( $n=43$ female and $n=43$ male) and the control group ( $\mathrm{n}=43$ female and $\mathrm{n}=43$ male), taking into account the gender factor by an independent researcher.

\section{Ethical considerations}

The necessary legal permission to carry out the research was obtained from the Local Ethics Committee (Decision No. 2017-246). Also, the individuals were given information concerning the research before the study started. After information was given, they signed an informed consent form concerning their voluntary participation.

\section{Measurements}

An individual identification form was used to collect information on individuals' age and gender. A 


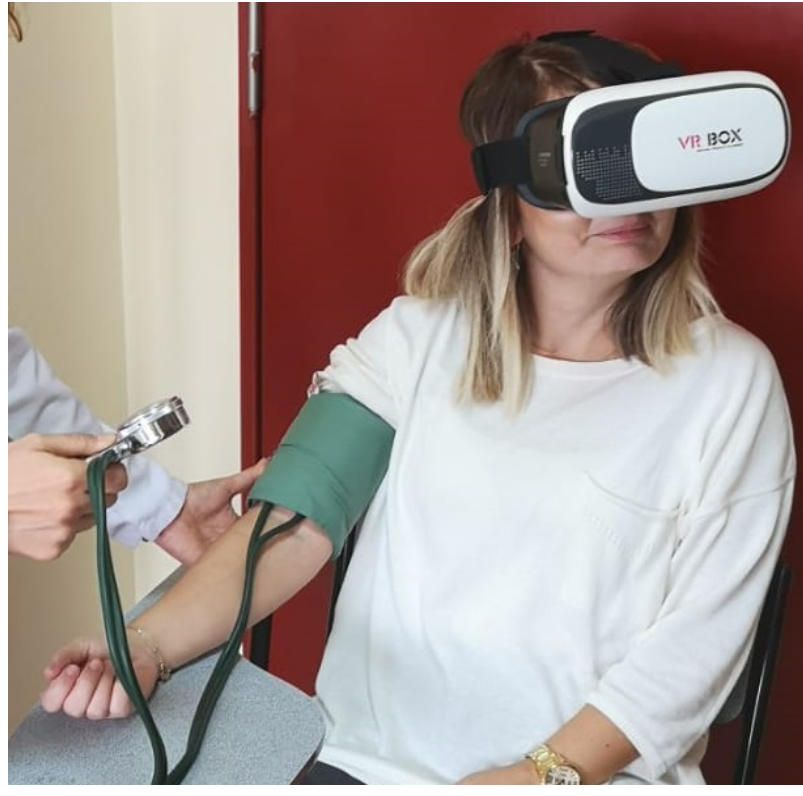

FIGURE 3. USING VR EQUIPMENT DURING PRACTICE

$10 \mathrm{~cm}$ vertical Visual Analog Scale (VAS) was used to evaluate the intensity of pain felt by the individuals during the procedure. One end indicated no pain, and the other end the worst possible pain ${ }^{18}$. Pain intensity scores were assessed in $\mathrm{cm}$.

"Roller coasters" was watched with a smartphone located in a VRBox headset. The images and realistic sounds created the feeling of being on a roller coaster in a virtual environment (Figure 1). Roller coaster is an application that gives the impression that people are moving in the speed of a train.

\section{Data Collection}

At the preparation stage of the study, an investigation was made with 10 people who were the same as the sample group, with the same equipment, and the same body part, to determine the mean $\mathrm{mmHg}$ and mean number of minutes needed to produce a sensation of pain. The minutes and pressure values at which these individuals felt the highest level of pain were determined and recorded. The averages of the determined pressure and minute values were calculated. As a result, the pain threshold for healthy individuals was set at $260 \mathrm{mmHg}$ for two minutes.

After the participants had been assured that their participation was voluntary, their identification data was collected on the form, and then they were given information on the use of the Visual Analog Scale. After that, in order to achieve standardization, the left arm of all individuals was supported at the level of the heart and $260 \mathrm{mmHg}$ pressure was applied 3-4 $\mathrm{cm}$ above the antecubital region for two minutes using an aneroid adult-type blood pressure instrument in order to induce pain.

While experimental ischemic pain was being applied to individuals in the experimental group, they were given "Roller Coasters" to watch using a virtual reality app on an android mobile phone placed in a VRBox headset (Figure 3). "Roller Coasters" was watched by the individuals in the experiment group, starting from one minute before the start of the procedure. After this procedure, the individuals' pain levels were assessed by an independent researcher using the VAS.

While experimental ischemic pain was being applied to individuals in the control group, no procedure was carried out to distract their attention. After the Experimental Ischemic Pain was applied, the individuals' pain levels were assessed by an independent researcher using the VAS. The research design of this study is shown in Figure 2.

\section{Data analysis}

Statistical analysis was performed using the Statistical Package for Social Sciences version 17.0 (SPSS Inc., Chicago, IL, USA). Shapiro-Wilk was used to examine normal distribution in numerical data. Distributions of identification data were given as means and standard deviation. The Mann-Whitney $\mathrm{U}$ test was used to compare both groups. A p-value $<0.05$ was considered significant.

\section{RESULTS}

There was a total of 172 participants in the study. The mean age of all participants was $19.69 \pm 0.77$ years. The mean age of individuals in the experimental groups was $20.0 \pm 1.00$ years, and in the control group, it was $19.38 \pm 0.94$ years. The differences between both groups in terms of gender and age were found not to be statistically significant ( $p$ > 0.05), and the groups were found to have homogeneous distribution.

When the mean pain scores of the groups were examined, we found that the mean pain score of individuals in the experimental group was $2.62 \pm 1.82$, while that of the individuals in the control group was $5.75 \pm 1.65$. The mean pain score of the individuals in the experimental group was found to be statistically significantly lower than that of the individuals in the control group $(p<0.001)$ (Table 1). 
TABLE 1. DISTRIBUTION OF PAIN SCORE OF EXPERIMENTAL AND CONTROL GROUPS

\begin{tabular}{l|l|l}
\multicolumn{2}{c}{ Experimental group } & Control group \\
\hline & Mean \pm SD & Mean \pm SD \\
\hline Pain score & $2.62 \pm 1.82$ & $5.75 \pm 1.65$ \\
\hline \multicolumn{2}{c}{$Z=-8.92 p<.001$} \\
\hline
\end{tabular}

$\mathrm{SD}=$ standart deviation; $\mathrm{Z}=$ Mann-Whitney $\mathrm{U}$ test

\section{DISCUSSION}

Pain is an unpleasant sensory and emotional experience in connection with actual or potential tissue damage or explained by this damage. Individuals can feel pain by focusing their limited attention capacity on the stimulus. For this reason, if a person's attention is directed away from the painful stimulus, the intensity of the pain experienced will be reduced ${ }^{9}$. Distraction is a cognitive behavioral technique used to reduce pain. Currently, this technique can be applied by means of the spatial illusion of virtual reality ${ }^{1}$. Virtual reality technology enables people to become immersed in a computer-simulated, three-dimensional environment ${ }^{13}$.

There are differences in the results of clinical research evaluating the efficacy of VR on pain. JahaniShoorab et $\mathrm{al}^{\mathbf{1 1}}$ reported that patients who used virtual reality had lower pain scores during episiotomy repair. Similarly, in the study conducted by Gou et $\mathrm{al}^{10}$, VR was effective in pain management on patients who had hand injury undergoing dressing change. However, Walker et al $^{\mathbf{1 7}}$ reported that the effect of VR on pain did not differ between the two groups studied during cystoscopy using lidocaine jelly.

In nonclinical research, VR has a positive effect on experimental pain. When pain was induced in healthy individuals by means of thermal stimuli, their brain functions were assessed using the functional magnetic resonance imaging technique, and it was found that the activity of the areas concerned with pain was significantly reduced in individuals using $\mathrm{VR}^{19}$. Supporting this result, virtual reality has been found to be effective in reducing pain created experimentally by cold pressure ${ }^{20}$. Sulea et $\mathrm{al}^{21}$ induced pain in healthy individuals using cold stimulus and mild electric shock methods and reported significantly lower pain scores in a group watching VR than in a group not watching VR. Another study comparing different methods concluded that for finger pressure pain, VR was a more effective method than hypnosis ${ }^{22}$. The results of our study are similar to that of other studies that investigated the effect of VR on pain. We too found that the use of virtual reality in healthy individuals subjected to pain by means of blood pressure was effective in reducing the levels of pain felt by diverting the attention away from the pain. Differently from other similar study results, our study used smartphones instead of computer-based software. VR can be used as a easy, cheap, and non-invasive method of pain management thanks to smartphones that have widespread availability and ease of transportation.

\section{CONCLUSION}

We found that the use of virtual reality to divert the attention elsewhere when healthy adults in the sample group were subjected to pain was an effective method in reducing the pain felt. Virtual reality created by smartphones can be effective for pain control and easily applied by health professionals for pain management aside from analgesic treatment.

\section{Limitations}

The study had some limitations. The results of the study are limited by the self-reporting of the individuals in the sample group. The method used in the study to inflict pain was manual. Also, although the pressure which created pain in the sample group of the study was determined as a standard in a pilot study, the true pain thresholds of individuals may be different. Thus, a further limitation in the study was that the pain thresholds of participants were not measured.

\section{RESUMO}

OBJETIVO: El objetivo de este estudio fue investigar el efecto de la aplicación de realidad virtual en el dolor isquémico experimental creado con un instrumento de presión arterial en voluntarios sanos.

MÉTODO: La muestra de investigación consistió en 172 estudiantes adultos voluntarios que cumplieron con los criterios de inclusión. A estos individuos se les asignó mediante un método de aleatorización simple en un grupo experimental $(n=86)$ y uno de control $(n=$ 86). Todos los individuos en los grupos experimentales y de control fueron sometidos experimentalmente a dolor durante dos minutos aplicando $260 \mathrm{mmHg}$ de presión 3-4 cm por encima de la región antecubital del brazo izquierdo con un instrumento de presión arterial 
aneroide tipo adulto. Durante el procedimiento, los voluntarios en el grupo experimental observaron imágenes de realidad virtual, mientras que los del grupo de control no recibieron ninguna intervención. Inmediatamente después del procedimiento, los niveles de dolor de los individuos en ambos grupos se evaluaron con una Escala Analógica Visual (EAV).

RESULTADOS: Se encontró que el puntaje promedio de dolor de los individuos en el grupo experimental fue $2.62 \pm 1.82$, y el de los individuos en el grupo control fue de $5.75 \pm 7.65$. Los resultados del análisis estadístico mostraron una diferencia estadísticamente significativa entre las puntuaciones medias de dolor de los individuos en los grupos experimental y control $(p<0,000)$.

CONCLUSÃo: Se encontró en este estudio que el uso de la realidad virtual fue efectivo para reducir el nivel de dolor en individuos sanos. Este método, que se lleva a cabo mediante el uso del teléfono inteligente y que ofrece una amplia disponibilidad y facilidad de transporte, puede ser utilizado por profesionales de la salud como un método no farmacológico en el tratamiento del dolor.

PALAVRAS-CHAVE: Realidad virtual. Dolor. Distracción.

\section{REFERENCES}

1. Sil S, Dahlquist LM, Thompson C, Hahn A, Herbert L, Wohlheiter K, et al. The effects of coping style on virtual reality enhanced videogame distraction in children undergoing cold pressor pain. | Behav Medi. 2014;37(1):156-65

2. Dissanayake DWN, Dissanayake DMD. The physiology of pain: an update and review of clinical relevance. J Ceylon Coll Phys. 2016;46(1-2):19-23.

3. Melzack R. Gate control theory: On the evolution of pain concepts. Pain Forum. 1996;5(2):128-38.

4. Legrain V, Damme SV, Eccleston C, Davis KD, Seminowicz DA, Crombez $G$. A neurocognitive model of attention to pain: behavioral and neuroimaging evidence. Pain. 2009;144(3):230-2.

5. Wiederhold BK, Gao K, Kong L, Wiederhold MD. Mobile devices as adjunctive pain management tools. Cyberpsychol Behav Soc Netw. 2014;17(6):385-9.

6. Amer A, Peralez, P. Affordable altered perspectives: making augmented and virtual reality technology accessible. [Internet]. Paper presented at the Global Humanitarian Technology Conference, San Jose, CA, USA; 2014 [cited 2018 March 1]. Available from: http://ieeexplore.ieee.org/document/6970345/

7. Kim KH, Kabir E, Jahan SA. The use of personal hair dye and its implications for human health. Envir Int. 2016;89-90:222-7.

8. Sun F, Zhang Z, Liao D, Chen T, Zhou l. A lightweight and cross-platform Web3D system for casting process based on virtual reality technology using WebGL. Int J Adv Manufacturing Tech. 2015;80(58):801-16.

9. Li A, Montaño Z, Chen V|, Gold II. Virtual reality and pain management: current trends and future directions. Pain. 2011;1(2):147-57.

10. Guo $C$, Deng $H$, Yang J. Effect of virtual reality distraction on pain among patients with hand injury undergoing dressing change. J Clin Nurs. 2015;24(1-2):115-20.

11. Jahanishoorab N, Zagami SE, Nahvi A, Mazluom SR, Golmakani N, Talebi $M$, et al. The effect of virtual reality on pain in primiparity women during episiotomy repair: A randomize clinical trial. Iranian J Med Sci. 2015;40(3):219-24
12. Maani CV, Hoffman HG, Morrow M, Maiers A, Gaylord K, McGhee LL, et al. Virtual reality pain control during burn wound debridement of combat-related burn injuries using robot-like arm mounted VR goggles. J Trauma. 2011;71(1):125-30.

13. Malloy KM, Milling LS. The effectiveness of virtual reality distraction for pain reduction: a systematic review. Clin Psychol Rev. 2010;30(8):1011-8.

14. Triberti S, Repetto C, Riva G. Psychological factors influencing the effectiveness of virtual reality-based analgesia: a systematic review. Cyberpsychol Behav Soc Netw. 2014;17(6):335-45.

15. Pandya PG, Kim TE, Howard SK, Stary E, Leng JC, Hunter OO, et al. Virtual reality distraction decreases routine intravenous sedation and procedure-related pain during preoperative adductor canal catheter insertion: a retrospective study. Korean | Anesthesiol. 2017;70(4):439-45.

16. Chan EA, Chung JW, Wong TK, Lien AS, Yang JY. Application of a virtual reality prototype for pain relief of pediatric burn in Taiwan. I Clin Nurs. 2007;16(4):786-93.

17. Walker MR, Kallingal GJ, Musser JE, Folen R, Stetz MC, Clark JY. Treatment efficacy of virtual reality distraction in the reduction of pain and anxiety during cystoscopy. Mil Med. 2014;179(8):891-6.

18. Kahl C, Cleland JA. Visual analogue scale, numeric pain rating scale and the McGill pain Questionnaire: an overview of psychometric properties. Physical Ther Revi. 2005;10(2):123-8.

19. Hoffman HG., Richards TL, Coda B, Bills AR., Blough D, Richards AL, et al. Modulation of thermal pain-related brain activity with virtual reality: evidence from fMRI. Neuroreport. 2004;15(8):1245-8.

20. Loreto-Quijada D, Gutiérrez-Maldonado |, Nieto R, Gutiérrez-Martínez O, Ferrer-García M, Saldaña C, et al. Differential effects of two virtual reality interventions: distraction versus pain control. Cyberpsychol Behav Soc Netw. 2014;17(6):353-8.

21. Sulea C, Soomro A, Wiederhlod BK, Wiederhlod MD. Quantifying the effectiveness of virtual reality pain management: a pilot study. Stud Health Tecnol Inform. 2014;199:94-7.

22. Enea V, Dafinoiu I, Opriş D, David D. Effects of hypnotic analgesia and virtual reality on the reduction of experimental pain among high and low hypnotizables. Int | Clin Exp Hypn. 2014;62(3):360-77. 